\title{
COLORIMETRIC DETERMINATION OF SERUM CHOLINESTERASE: ITS VALUE IN HEPATIC AND BILIARY TRACT DISEASES ${ }^{1}$
}

\author{
By M. H. SLEISENGER, T. P. ALMY, H. GILDER, AND G. PERLE \\ (From the Department of Medicine, The New York Hospital, Cornell Medical Center, \\ New York, N. Y.)
}

(Submitted for publication November 21, 1952; accepted February 11, 1953)

In the past few years there has been renewed interest in the study of serum cholinesterase in various disease states, particularly those affecting the liver.

Recently, a colorimetric method for the determination of this enzyme in the serum was reported by Ravin, Tsou, and Seligman (1). Their method, simple to perform, is as accurate as the gastrometric technique and more specific than the electrometric $(2,3)$. These advantages seemed to warrant an evaluation of its usefulness in prognosis of hepatic disease and in the differential diagnosis of jaundice.

\section{MATERIALS AND METHODS}

The colorimetric method is based upon the hydrolysis of carbonaphthoxycholine iodide, a choline ester, by serum cholinesterase. $\beta$-naphthol, liberated after incubation, combines with a diazonium salt, tetrazotized diorthoanisidine, to yield a colored dye, extractable with ethyl acetate, which is read in a Klett-Summerson colorimeter. Readings are converted to mg. of $\beta$-naphthol from a calibration curve and thence to units per $100 \mathrm{cc}$. of serum. One unit is defined as that amount of enzyme which liberates $10 \mathrm{mg}$. of $\beta$-naphthol per hour (1).

Sera were tested freshly drawn or after a few days' storage at 2 to $4^{\circ} \mathrm{C}$. There was no change in enzyme activity after such storage. Substrate solution was also stored at $4^{\circ} \mathrm{C}$. and was not used after 72 hours. All determinations were made in duplicate. There was no difference in serum cholinesterase between fasting and post-prandial samples. Serial determinations were done on all cases of acute viral hepatitis and on many cases of advanced cirrhosis of the liver.

Serum albumin was estimated in most instances by a modification of the Kingsley method, using 24.5 per cent $\mathrm{Na}_{2} \mathrm{SO}_{4}$ to precipitate the globulin fraction (4). In a correlation study of albumin with serum cholinesterase in 54 subjects, the immunological technique of Kunkel and Ward was employed (5), and parallel determinations of albumin were done on the same sera according to the micro-Kjeldahl procedure (6). In normal subjects the results differed by $0.2 \mathrm{gm}$. or less; in the cirrhotics the

${ }^{1}$ Supported in part by a grant from G. D. Searle \& Co., Chicago, Illinois. values obtained by the immunological method were consistently lower than those by the micro-Kjeldahl technique.

In addition, the following liver function tests were done with modifications by the Central Chemistry Laboratory of The New York Hospital: thymol turbidity according to MacLagan (7); cephalin-cholesterol flocculation method of Frisch and Quilligan (8); total serum bilirubin according to Malloy and Evelyn (9); alkaline phosphatase by the method of Bodansky (10), but with the Fiske and Subbarow method for the determination of phosphorus (11), and bromsulphalein excretion according to Rosenthal and White (12).

\section{RESULTS}

Sera of 47 normal subjects, 47 patients with cirrhosis of the liver and 13 with acute viral hepatitis were tested. Healthy hospital personnel constituted the control group. About half of the cirrhotics were ambulatory outpatients; the remaining half of this group and all cases of acute viral hepatitis were patients on the wards of The New York Hospital. In all instances the diagnosis was supported by accepted hepatic function studies and in a few by histological study. The range of values in normal subjects and patients with liver disease is presented graphically in Figure 1.

The range in the control group was from 19.2 to 50.6 units, with a mean of 29.6. The standard deviation was \pm 7.1 .

The cases of hepatic cirrhosis are subdivided according to their functional state, i.e., "compensated" or "decompensated." Patients with jaundice, edema or ascites were placed in the latter category. There were 23 patients with compensated cirrhosis, whose serum cholinesterase ranged from 8.0 to 38.4 units with an average of 19.6 units. Twenty-four patients with hepatic decompensation had from less than 1.0 to 13.3 units with a mean of 5.0 units. (The value 0.5 was used for readings less than 1.0 in calculations of the mean.)

The initial values for cholinesterase in $12 \mathrm{pa}$ tients with acute viral hepatitis ranged from 5.3 
to 25.6 units with an average of 16.1 units. The first determination on the thirteenth case was done at the end of the third week of jaundice and was 35.6 units.

The extent of correlation of the initial level of serum cholinesterase with the subsequent clinical course is noted in Table $I$. Of 24 patients with decompensated cirrhosis, 16 had values of 5.4 units or less, and of these, 9 died in hepatic coma from within a few days to a few months. All patients with less than 1.0 unit died in less than two weeks. Two patients with less than 5.3 units recovered and the course of one of these is charted in Figure 2. Although the range of values in compensated cirrhosis was wide, none of these patients showed significant clinical changes over a period of months.

Twelve patients with acute viral hepatitis recovered completely. There was a progressive rise of serum cholinesterase in all cases (Figure 3 ). One patient with an initial level of 5.3 units died within one week and at autopsy showed massive hepatic necrosis.

Concomitant studies of other liver functions were done in many of the cirrhotics who had decompensation and in cases of acute viral hepatitis.

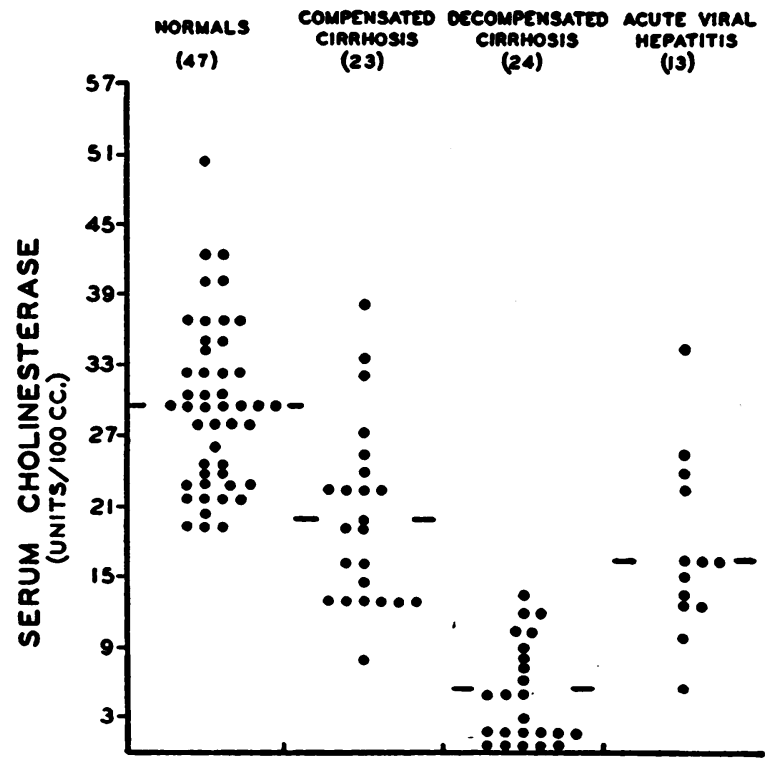

Fig. 1. Range of Values of Serum Cholinesterase in Normal Subjects and Patients with Liver DisEASE

The bars indicate the mean values.

All modalities tested showed obvious impairment and with recovery there was return to normal or near normal values of all tests (Table II). There

TABLE I

Prognosis of liver disease at various levels of serum cholinesterase (single determinations)

\begin{tabular}{|c|c|c|c|c|}
\hline $\begin{array}{l}\text { No. } \\
\text { cases }\end{array}$ & Diagnosis & Functional state & $\begin{array}{l}\text { Serum } \\
\text { cholinesterase } \\
\text { units/100 cc. }\end{array}$ & Clinical course \\
\hline 5 & Cirrhosis & Decompensated & $0-1.0$ & All dead within 2 weeks \\
\hline 11 & $\begin{array}{l}\text { Cirrhosis } \\
\text { Viral hepatitis }\end{array}$ & $\begin{array}{l}\text { Decompensated } \\
\text { Comatose }\end{array}$ & $1.1-5.3$ & $\begin{array}{l}4 \text { dead within } 2 \text { months } \\
1 \text { declining } \\
4 \text { stationary } \\
2 \text { improved* } \\
\text { Dead in one week }\end{array}$ \\
\hline $\begin{array}{l}1 \\
1\end{array}$ & $\begin{array}{l}\text { Cirrhosis } \\
\text { Cirrhosis } \\
\text { Viral hepatitis }\end{array}$ & $\begin{array}{l}\text { Decompensated } \\
\text { Compensated } \\
\text { Severely ill }\end{array}$ & $5.4-10.1$ & $\begin{array}{l}1 \text { dead in } 2 \text { months } \\
3 \text { stationary } \\
2 \text { improved } \\
\text { Stationary } \\
\text { Recovery }\end{array}$ \\
\hline $\begin{array}{l}2 \\
7 \\
2\end{array}$ & $\begin{array}{l}\text { Cirrhosis } \\
\text { Cirrhosis } \\
\text { Viral hepatitis }\end{array}$ & $\begin{array}{l}\text { Decompensated } \\
\text { Compensated } \\
\text { Moderately ill }\end{array}$ & $10.2-13.3$ & $\begin{array}{l}1 \text { dead in } 1 \text { month } \\
1 \text { stationary } \\
\text { All stationary } \\
\text { Both recovered }\end{array}$ \\
\hline $\begin{array}{l}5 \\
4\end{array}$ & $\begin{array}{l}\text { Cirrhosis } \\
\text { Viral hepatitis }\end{array}$ & $\begin{array}{l}\text { Compensated } \\
\text { Moderately ill }\end{array}$ & $13.4-19.6$ & $\begin{array}{l}1 \text { decompensating } \\
4 \text { stationary } \\
\text { All recovered }\end{array}$ \\
\hline $\begin{array}{r}10 \\
5\end{array}$ & $\begin{array}{l}\text { Cirrhosis } \\
\text { Viral hepatitis }\end{array}$ & $\begin{array}{l}\text { Compensated } \\
\text { Moderately ill }\end{array}$ & $19.7-38.4$ & $\begin{array}{l}\text { All stationary } \\
\text { All recovered }\end{array}$ \\
\hline
\end{tabular}

* The course of one of these patients is charted below. 


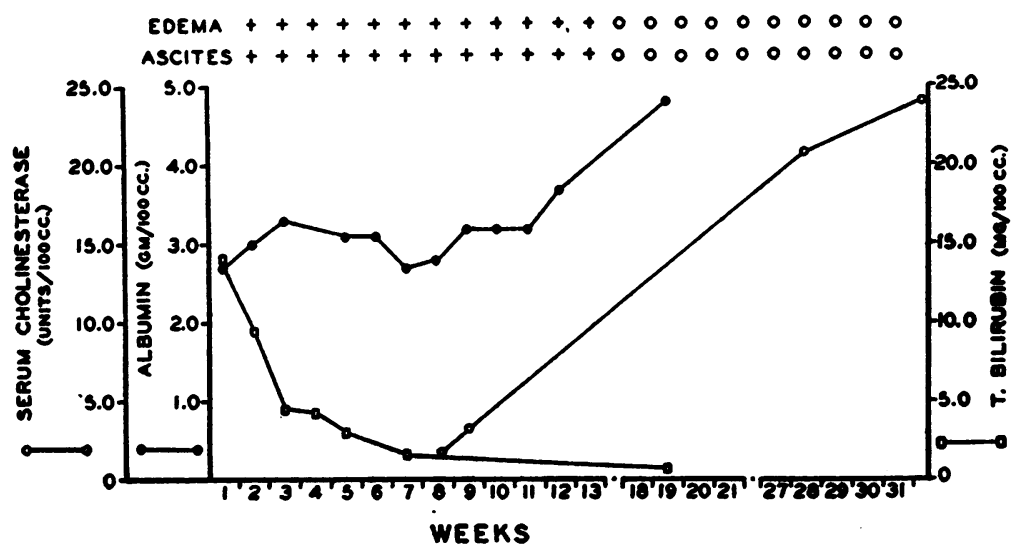

Fig. 2. Recovery from Decompensated CirRhosis

was no case in which the serum cholinesterase was the sole indication of the degree of hepatic damage or recovery. These results indicate that in the detection of severe hepatic damage serum cholinesterase is not superior to other accepted liver function tests.

Single determinations of serum cholinesterase in 22 normal subjects, 16 cases of decompensated

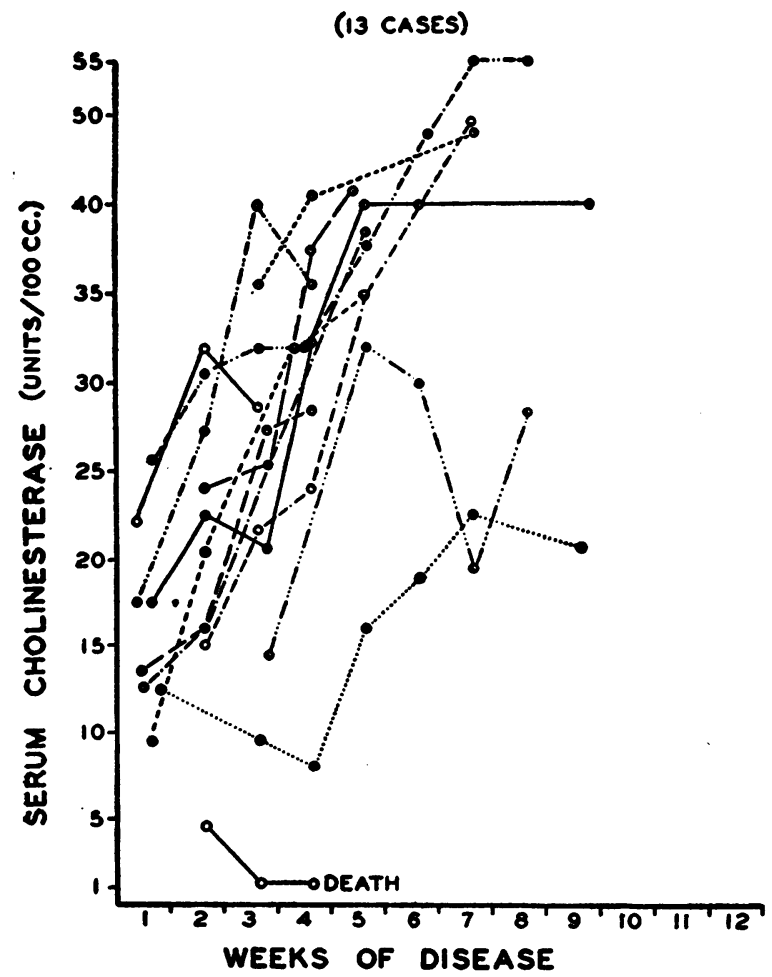

Fig. 3. Rise in Serum Cholinesterase in Recovery of Viral Hepatitis cirrhosis, 8 cases of compensated cirrhosis and 8 patients with wasting diseases were plotted against serum albumin performed by the immunological method (Figure 4). Of the latter eight cases, six had widespread malignancies, one had chronic intractable ulcerative colitis and one had weight loss and edema following massive resection of the small intestine for thrombosis of the mesenteric artery.

With one exception, all cases with a normal serum albumin had a normal serum cholinesterase. In one cirrhotic, recovering from a bout of decompensation, the rise in cholinesterase lagged behind the rise in albumin. This lag during recovery from a variety of diseases has been noted by Faber (13). Those patients with low albumin also had low serum cholinesterase. Of interest are the normal values for both serum cholinesterase and albumin in two cases of the "malnutritionmalignancy" group. One patient was suffering from chronic ulcerative colitis with weight loss and anorexia and the other was gravely ill with advanced intra-abdominal carcinomatosis.

The relationship between serum albumin and serum cholinesterase is further shown in Figure 5 , on which is plotted the parallel rise in values of the two determinations during recovery from hepatitis. In this study the Kingsley method for albumin was considered satisfactory because serial determinations were done upon the same individual.

Seven patients with jaundice due to extrahepatic obstruction were studied (Cases 1-7, Table III). A single determination of serum cholinesterase in these cases was compared with five other tests. Cases 1 and 2 with obstruction 
TABLE II

Average values of serum cholinesterase and six other liver function tests in decompensated cirrhosis and acute viral hepatitis

\begin{tabular}{|c|c|c|c|c|c|c|c|}
\hline & $\begin{array}{l}\text { Serum } \\
\text { cholinesterase } \\
\text { units/100 cc. }\end{array}$ & $\begin{array}{c}\text { Serum } \\
\text { albumin } \\
\text { gm./100 cc. }\end{array}$ & $\underset{\substack{\text { Total } \\
\text { bilirubin } \\
\text { mg.1100 cc. }}}{.}$ & $\begin{array}{l}\text { Cephalin } \\
\text { flocc. } \\
\text { units }\end{array}$ & $\begin{array}{l}\text { Thymol } \\
\text { turb. } \\
\text { units }\end{array}$ & $\begin{array}{c}\text { Alkaline } \\
\text { phosphatase } \\
\text { Bodansky } \\
\text { units }\end{array}$ & $\begin{array}{c}\text { B.S.P. } \\
\text { (\%) } \\
5 \text { mg./Kg.l } \\
45 \text { min. }\end{array}$ \\
\hline $\begin{array}{l}\text { Decompensated } \\
\text { cirrhosis } \\
\text { (24) }\end{array}$ & 5.0 & 3.3 & 9.2 & 12.7 & 7.7 & $\begin{array}{l}\text { Portal }-8.6 \\
\text { Biliary-31.3 }\end{array}$ & 40.1 \\
\hline $\begin{array}{l}\text { Initial acute } \\
\quad \text { viral hepatitis }\end{array}$ & 15.4 & 3.9 & 17.1 & 9.2 & 14.0 & 10.6 & 46.3 \\
\hline $\begin{array}{r}\text { Recovery } \\
\text { (13) }\end{array}$ & 38.1 & 5.0 & 1.5 & 5.1 & 11.0 & 4.7 & 7.7 \\
\hline Normal & $19.2-50.0$ & $4.5-5.5$ & $0.1-0.8$ & $0-5.0$ & $0-4.0$ & $2.0-4.0$ & $0-5 \%$ \\
\hline
\end{tabular}

due to choledocholithiasis had normal values for serum cholinesterase which afforded evidence against diffuse hepatic disease; however, both of these patients had histories compatible with longstanding biliary tract disease and their other studies pointed strongly toward extra-hepatic obstruction. Cases 3-7 had jaundice secondary to carcinoma; four patients had carcinoma of the head of the pancreas and one had carcinoma of the bile ducts. In all these instances the serum cholinesterase was depressed. This test was the only evidence which suggested diffuse hepatic disease and could have been misleading.

Finally, two cases of acute viral hepatitis (Cases 8 and 9) are represented in the table. Both cases were entering their fourth week of jaundice, both had histories which were atypical for hepatitis, and the liver was only slightly enlarged and non-tender in both instances. The normal value of $\mathbf{3 5 . 6}$ units in Case 8 was consistent with other laboratory values which also indicated extra-hepatic obstruction. In Case 9, the serum cholinesterase was at the lower limit of normal, and compatible with hepatitis or with possible malignant obstruction. In both instances, single determinations of cholinesterase served to confuse rather than clarify the differential diagnosis.

\section{DISCUSSION}

The hypothesis that serum cholinesterase is synthesized by the liver rests on both clinical evidence and experimental data. The depression of the plasma level in parenchymatous disease of the liver

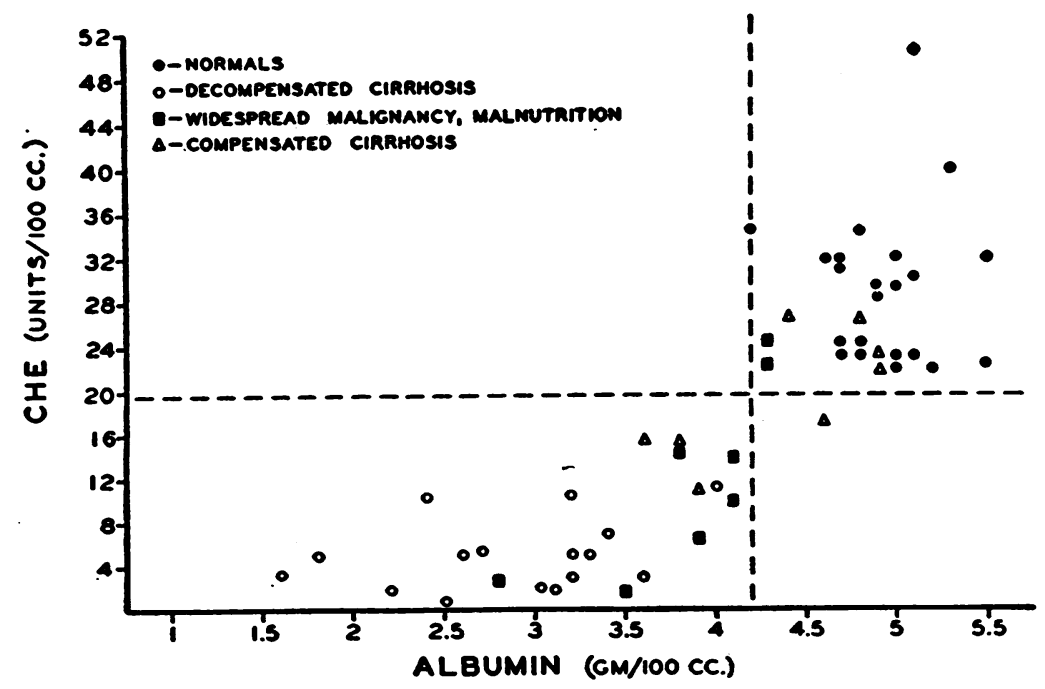

Fig. 4. Serum Albumin versus Cholinesterase 


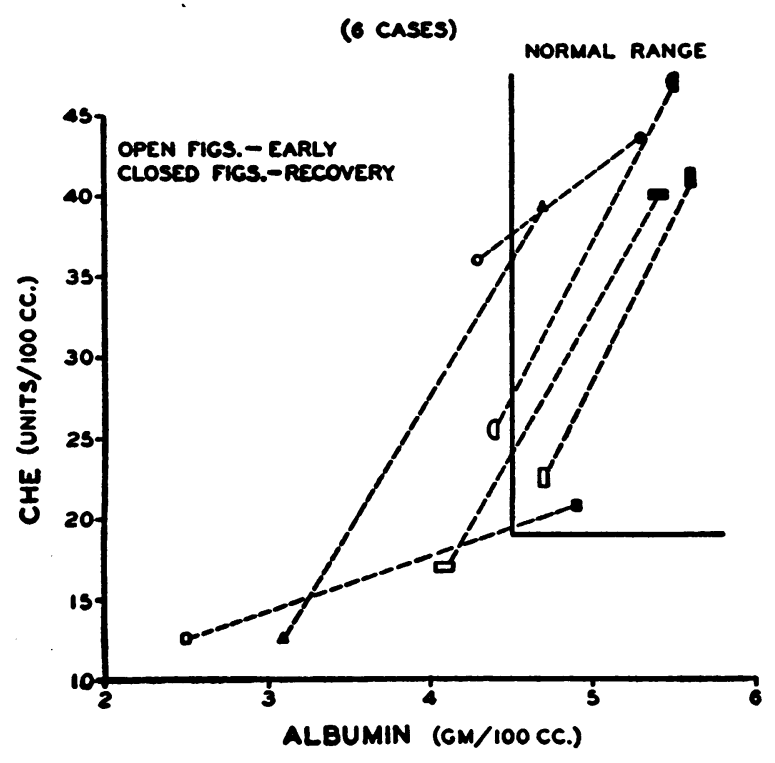

Fig. 5. Serum Cholinesterase versus Albumin in Early Hepatitis ANd ON Recovery

and its rise upon recovery has been observed repeatedly (14-21). Brauer and Root have shown that in rats and dogs, after a latent period, liver damage, incident to carbon tetrachloride administration, is associated with lowering of the plasma cholinesterase $(22,23)$. Wescoe, Hunt, Riker, and Litt gave $2 \mathrm{mg}$. di-isopropylfluorophosphate to normal subjects and patients with liver disease and found that the rate of regeneration of the enzyme was depressed in the latter group (24).

A third bit of evidence has been the correlation of serum albumin with serum cholinesterase in liver disease and other disease states $(13,14,18$, 25). Broadly, the evidence presented above substantiates this correlation and suggests that the protein synthetic function of the liver may be studied in hepatic disease by serial determinations of cholinesterase.

The clinical value of the determination is debatable. The test seems to be useful as a prognostic sign in advanced hepatic disease and in following the course of acute hepatitis but, in our experience, is no more informative than close clinical observation. In recovery from acute viral hepatitis, the rise in serum occurred in association with the fall in bilirubin in all instances, save one. Also, we would agree with Mann, Mandel, Eichman, Knowlton, and Sborov that in chronic hepatic disease of lesser severity the test is not helpful as an indicator of the degree of liver damage (19). The average value for serum cholinesterase in our series of compensated cirrhotics was 19.8 units, which is at the lower limit of normal. Further, in all cases of decompensated cirrhosis and acute viral hepatitis, both during the illness and upon recovery, the test gave no information beyond that afforded by other routine tests (17) (Table II). It is still possible that the return to normal of serum cholinesterase may best indicate the earliest point in the recovery from hepatic injury, at which the patient may be allowed full activity. Further observations will be needed to determine this.

In the important sphere of differentiation between "extra-hepatic" and "intra-hepatic" causes of jaundice, individual determinations of serum cholinesterase may be misleading. Low levels are found in extra-hepatic obstruction due to malignancy, possibly due to malnutrition or impairment of liver function by metastases $(14,25,26)$. Also, the initial level in a patient with acute viral hepatitis may be in the normal range, being diminished only in relation to that individual's level when in the healthy state (21). While it is true that a

TABLE III

Comparison of serum cholinesterase with other data in differential diagnosis of jaundice

\begin{tabular}{|c|c|c|c|c|c|c|c|c|c|}
\hline $\begin{array}{l}\text { Case } \\
\text { No. }\end{array}$ & Age & Sex & $\begin{array}{l}\text { Duration } \\
\text { jaundice }\end{array}$ & $\begin{array}{c}\text { Serum } \\
\text { cholines- } \\
\text { terase } \\
\text { units/100 cc. }\end{array}$ & $\begin{array}{l}\text { Cephalin } \\
\text { flocc. } \\
\text { units }\end{array}$ & $\begin{array}{l}\text { Thymol } \\
\text { turb. } \\
\text { units }\end{array}$ & $\begin{array}{c}\text { Alkaline } \\
\text { phosphatase } \\
\text { Bodarsky } \\
\text { units }\end{array}$ & $\underset{\text { mg./100 cc. }}{\text { Bilirubin }}$ & Diagnosis \\
\hline $\begin{array}{l}1 \\
2 \\
3 \\
4 \\
5 \\
6 \\
7 \\
8 \\
9\end{array}$ & $\begin{array}{l}34 \\
56 \\
65 \\
79 \\
63 \\
62 \\
62 \\
35 \\
38\end{array}$ & $\begin{array}{l}\mathbf{F} \\
\mathbf{F} \\
\mathbf{F} \\
\mathbf{F} \\
\mathbf{M} \\
\mathbf{M} \\
\mathbf{F} \\
\mathbf{M} \\
\mathbf{F}\end{array}$ & $\begin{array}{l}2 \text { mos. } \\
1 \text { mo. } \\
2 \text { mos. } \\
3 \text { wks. } \\
3 \text { wks. } \\
2 \frac{1}{2} \text { mos. } \\
1 \text { wk. } \\
3 \text { wks. } \\
3 \text { wks. }\end{array}$ & $\begin{array}{r}20.8 \\
28.8 \\
15.5 \\
5.3 \\
14.4 \\
12.8 \\
2.7 \\
35.6 \\
17.4\end{array}$ & $\begin{array}{l}3 \\
2 \\
7 \\
5 \\
2 \\
4 \\
3 \\
0 \\
7\end{array}$ & $\begin{array}{l}4 \\
2 \\
8 \\
1 \\
4 \\
1.0 \\
1.0 \\
11\end{array}$ & $\begin{array}{r}13.4 \\
17.3 \\
6.1 \\
31.1 \\
12.2 \\
27.0 \\
11.4 \\
8.4 \\
11.2\end{array}$ & $\begin{array}{r}6.2 \\
-\quad 4.0 \\
1.8 \\
17.8 \\
9.5 \\
13.6 \\
12.5 \\
4.1 \\
22.2\end{array}$ & $\begin{array}{l}\text { Choledocholithiasis } \\
\text { Choledocholithiasis } \\
\text { CA head pancreas } \\
\text { CA head pancreas } \\
\text { CA head pancreas } \\
\text { CA head pancreas } \\
\text { CA bile ducts } \\
\text { Viral hepatitis } \\
\text { Viral hepatitis }\end{array}$ \\
\hline
\end{tabular}


rising level of serum cholinesterase indicates recovery from hepatic damage, this rise can be demonstrated only after days or weeks, by which time the clinical diagnosis has become apparent.

\section{SUM MARY}

In 47 normal subjects the average level of serum cholinesterase as determined colorimetrically was 29.6 units per $100 \mathrm{cc}$. (range, 19.2 to 50.6 ). Corresponding values for 24 decompensated cirrhotics were 5.0 units ( $<1.0$ to 13.3 ) ; for 23 compensated cirrhotics, 19.6 units ( 8.0 to 38.4 ) ; and for 13 cases of acute viral hepatitis, 16.1 units (5.3 to 25.6 ). In 10 cases diagnosed clinically as obstructive jaundice, the level was depressed in five with pancreatic carcinoma, normal in three with choledocholithiasis and normal in two cases of viral hepatitis.

In serial determinations the level of serum cholinesterase reflected faithfully the course of acute viral hepatitis and decompensated cirrhosis. In no instance, however, did it contradict the clinical impression and other laboratory evidence.

Single determinations of serum cholinesterase in 54 subjects ( 22 controls, 24 cirrhotics, and 8 cases of malnutrition) were plotted against serum albumin determined by an immunological method. With one exception, those cases with normal albumin had normal cholinesterase and those with depressed albumin had low cholinesterase. This relationship was further shown by the gradual rise in both values during recovery from acute viral hepatitis.

\section{ACKNOWLEDGMENTS}

The authors wish to express their appreciation to Dr. Irwin D. J. Bross for statistical help, to Miss Bebe Mensch for technical assistance, and to Miss Ella Russ and Drs. Herbert A. Ravin, Arnold M. Seligman, Mary Ann Payne, and Warren B. Nestler for their interest and advice.

\section{REFERENCES}

1. Ravin, H. A., Tsou, K.-C., and Seligman, A. M., Colorimetric estimation and histo-chemical demonstration of serum cholinesterase. J. Biol. Chem., 1951, 191, 843.

2. Ammon, R., Die fermentative Spaltung des Acetylcholins. Arch. f. d. ges. Physiol., 1933, 233, 486.

3. Michel, H. O., An electrometric method for the determination of red blood cell and plasma cholinesterase activity. J. Lab. \& Clin. Med., 1949, 34, 1564.
4. Kingsley, G. R., The determination of serum total protein, albumin, and globulin by the Biuret reaction. J. Biol. Chem., 1939, 131, 197.

5. Kunkel, H. G., and Ward, S. M., The immunological determination of human albumin in biological fluids. J. Biol. Chem., 1950, 182, 597.

6. Hiller, A., Plazin, J., and Van Slyke, D. D., A study of conditions for Kjeldahl determination of nitrogen in proteins. Description of methods with mercury as catalyst, and titrimetric and gasometric measurements of the ammonia formed. J. Biol. Chem., 1948, 176, 1401.

7. MacLagan, N. F., Thymol turbidity test: a new indicator of liver dysfunction. Nature, 1944, 154, 670.

8. Frisch, A. W., and Quilligan, J. J., A modified cephalin cholesterol test (Hanger) in the study of hepatic disease. Am. J. M. Sc., 1946, 212, 143.

9. Malloy, H. T., and Evelyn, K. A., The determination of bilirubin with the photoelectric colorimeter. J. Biol. Chem., 1937, 119, 481.

10. Bodansky, A., Phosphatase studies. II. Determination of serum phosphatase. Factors influencing the accuracy of the determination. J. Biol. Chem., 1933, $101,93$.

11. Fiske, C. H., and Subbarow, Y., The colorimetric determination of phosphorus. J. Biol. Chem., 1925, 66, 375.

12. Rosenthal, S. M., and White, E. C., Clinical application of the bromsulphalein test for hepatic function. J. A. M. A., 1925, 84, 1112.

13. Faber, M., The relationship between serum cholinesterase and serum albumin. Acta. med. Scandinav., 1943, 114, 72.

14. Orellana Alcalde, J. M., Serum cholinesterase determination in the differential diagnosis of jaundice. J. Lab. \& Clin. Med., 1950, 36, 391.

15. Antopol, W., Schifrin, A., and Tuchman, L., Decreased choline-esterase activity of serum in jaundice and in biliary disease. Proc. Soc. Exper. Biol. \& Med., 1938, 38, 363.

16. Faber, M., Serum cholinesterase in disease. Acta. med. Scandinav., 1943, 114, 59.

17. Grob, D., Lilienthal, J. L., Jr., Harvey, A. M., and Jones, B. F., The administration of di-isopropyl fluorophosphate (DFP) to man. I. Effect on plasma and erythrocyte cholinesterase; general systemic effects; use in study of hepatic function and erythropoiesis; and some properties of plasma cholinesterase. Bull. Johns Hopkins Hosp., 1947, 81, 217.

18. Kunkel, H. G., and Ward, S. M., Plasma esterase activity in patients with liver disease and the nephrotic syndrome. J. Exper. Med., 1947, 86, 325.

19. Mann, J. D., Mandel, W. I., Eichman, P. P., Knowlton, M. A., and Sborov, V. M., Serum cholinesterase activity in liver disease. J. Lab. \& Clin. Med., 1952, 39, 543. 
20. McArdle, B., The serum choline esterase in jaundice and diseases of the liver. Quart. J. Med., 1940, 9, 107.

21. Vorhaus, L. J., II, Scudamore, H. H., and Kark, R. M., Measurement of serum cholinesterase activity in the study of diseases of the liver and biliary system. Gastroenterology, 1950, 15, 304.

22. Brauer, R. W., and Root, M. A., Liver injury and its influence upon the acetylcholine splitting activity of rat and dog. Federation Proc., 1946, 5, 168.

23. Brauer, R. W., and Root, M. A., The effect of carbon tetrachloride induced liver injury upon the acetylcholine hydrolyzing activity of blood plasma of the rat. J. Pharmacol. and Exper. Therap., 1946, 88, 109.

24. Wescoe, W. C., Hunt, C. C., Riker, W. F., and Litt, I. C., Regeneration rates of serum cholinesterase in normal individuals and in patients with liver damage. Am. J. Physiol., 1947, 149, 549.

25. Levine, M. G., and Hoyt, R. E., The relationship between human serum cholinesterase and serum albumin. Science, 1950, 111, 286.

26. McCance, R. A., Widdowson, E. M., and Hutchinson, A. O., Effect of undernutrition and alterations in diet on the choline esterase activity of serum. Nature, 1948, 161, 56. 